\title{
Does straw retention sustain soil carbon stocks in Brazilian sugarcane fields?
}

\author{
Sarah Tenelli ${ }^{1}$, Ricardo Bordonal ${ }^{2}, \mathrm{MR}_{\text {Cherubin }}{ }^{3}, \mathrm{C} \mathrm{Cerri}^{3}$, and João Carvalho ${ }^{2}$ \\ ${ }^{1}$ UNICAMP \\ ${ }^{2} \mathrm{CNPEM}$ \\ ${ }^{3}$ USP ESALQ
}

May 7, 2020

\begin{abstract}
Sugarcane straw is a crop residue known as the main input of carbon $(\mathrm{C})$ to the soil, but its removal represents a valuable asset for bioenergy purposes, which may adversely affect soil organic C (SOC) stocks. Most studies related to this issue is limited to site-specific conditions and comprehensive studies in a wide range of soils and climate regions are scarce. This study was designed to evaluate temporal SOC stocks changes induced by sugarcane cultivation and straw management in the southerncentral of Brazil. Ten field experiments were arranged in a randomized block design with four replications, including four straw removal rates: total (TR), high (HR), low (LR) and no removal (NR). Soil samples were collected to a 30-cm depth at the beginning of the trial establishment and after four consecutive years. The dataset suggested that $19 \%$ and $25 \%$ of the $\mathrm{C}$ added via straw were accumulated into the soil of the sandy and clayey areas, respectively. This study showed strong SOC depletion in sandy soils at rates of $1.4,1.5,1.9$ and $2.3 \mathrm{Mg}$ ha- 1 year-1 under NR, LR, HR and TR, respectively. In contrast, clayey soils exhibited SOC accumulation over time, even removing all the straw from the soil surface. Based on SOC changes, these findings provide a robust scientific basis to support policy and management decisions for straw-derived bioenergy, showing that the removal of sugarcane straw may be potentially advantageous in clayey soils but should be avoided in sandy soils of tropical regions in Brazil.
\end{abstract}

\section{Introduction}

Soil organic carbon (SOC) plays a crucial role for mitigating global climate change (FAO, 2019; IPCC, 2019). However, the intensification of monocropping has grown steadily and, when poorly managed, it has caused serious soil degradation problems, leading to significant SOC losses to the atmosphere (Sanderman et al., 2017). Because soil pool has the potential to store three times as much $\mathrm{C}$ as the atmosphere (Lal, 2004; Sanderman et al., 2017), public policy incentive for collective actions has been proposed in applying management strategies to rebuild SOC stocks (Vermeulen et al., 2019). Soils that are inadequately managed can be source of $\mathrm{CO}_{2}-\mathrm{C}$ emissions, but sustainably managed soils can considerably contribute to $\mathrm{C}$ sequestration, helping to reduce global warming (FAO, 2019; IPCC, 2019) and providing key soil-related ecosystem services (Lorenz et al., 2019).

Globally, sugarcane (Saccharum spp.) stands out as a crop with a sustainable potential to minimize the agricultural C footprint. Sugarcane-derived bioethanol is one of the most promising renewable energy alternatives to petroleum-based transport fuels and, is recognized for its potential ability to emit less C in the life cycle and avoid negative impacts on food security and biodiversity (Bordonal et al., 2018). Brazil 
is the largest world producer of sugarcane, with a production of 30 billion L of bioethanol from a cultivated area of 9.9 million hectares (Conab, 2019). In the last decades, concerns about the sustainability of sugarcane cultivation under pre-harvest burning in Brazil led to major changes in crop harvesting practices so that burned manual harvesting has been gradually replaced by a green mechanized system. This new harvest system resulted in a thick layer of straw (10-20 $\mathrm{Mg} \mathrm{ha}^{-1}$ ) returned to the soil, thus providing several agro-environmental benefits such as SOC accretion, microbiota support, nutrient cycling and improved soil structure (Carvalho et al., 2017; Cerri et al., 2011).

More recently, the sugarcane sector has shown interest in the removal of sugarcane straw for bioenergy production. The increased use of bioenergy from sugarcane straw has been triggered by sectoral policies such as Renovabio program driven by international commitments under the Paris Convention of the Parties (COP 21) as a potential renewable substitute for fossil fuels (IPCC, 2019). Nevertheless, recent studies have confirmed that the indiscriminate removal of agricultural residues from several crops leads to SOC depletion (Bordonal et al., 2018b; Cherubin et al., 2018; Xu et al., 2019). In particular, special attention should be given to the straw removal in coarse-textured soils, since these soils usually are less resilient to SOC losses (Bordonal et al., 2018b). There exists a strong interaction between clay fraction and SOC, so that clay particles tend to form aggregates that physically protect SOC against microbial and enzymatic attack (Dieckow et al. 2009). However, there is a lack of comprehensive studies evaluating the effects of straw removal on SOC stocks in different soil types and climate conditions in Brazil to provide a robust scientific basis for public policy and management decisions.

Based on this concern, we hypothesized that (i) high rates of sugarcane straw removal for bioenergy production intensify SOC stocks depletion; (ii) the removal of straw is more deleterious to SOC stocks in sandy than in clayey soils in Brazilian conditions. To test these hypotheses, we conducted a set of ten field experiments to evaluate the temporal changes of SOC stocks in sugarcane fields under straw removal across diverse edaphoclimatic conditions in central-southern Brazil, the largest sugarcane-producing region in the country. Specific goals were to evaluate SOC changes induced by sugarcane monocropping cultivation, as well as to determine SOC responses to straw removal rates in sandy and clayey soils. Additionally, we determined the minimum amount of straw required to sustain the SOC levels for sandy and clayey soils.

1.

\section{Material and methods \\ Description of the study areas}

Ten field experiments were conducted in southern-central region of Brazil, covering areas under sugarcane production in Goiás and São Paulo, the two largest sugarcane-producing states of the country (Fig. 1). The field experiments were setup under contrasting conditions of climate and soil and conducted along the crop cycle within commercial areas of sugarcane production. Descriptions of each experimental site (e.g., municipalities, soil classification, texture, altitude, precipitation and temperature), as well as details about the characterization of the soil chemical and physical attributes at the beginning of each field experiment are shown in Tables 1 and 2. In order to simplify the data analyzes, the experiments were categorized in two groups according to soil texture as follows: i) clayey soils $=$ soils with $>33 \%$ of clay and ii) sandy soils $=$ soils with $<23 \%$ of clay.

\subsection{Experimental design and treatments}

Each one of the ten field experiments were arranged in a randomized block design with four replications. Each individual plot was dimensioned with 10-m long by 12-m wide, containing eight sugarcane rows spaced 1.5- $\mathrm{m}$. The treatments of straw management were established after the plant cane harvesting, when straw is available in sugarcane fields. After sugarcane harvesting, the exact amount of straw produced in each area was quantified through a metallic frame $\left(0.25 \mathrm{~m}^{2}\right)$ randomly thrown in the field ten times. Straw moisture was measured directly in the field using the sensor AL-104 Agrologic ${ }^{\circledR}$ with E-831 Electrode coupled. After 
quantification of straw dry mass, the adjustment of each dose of straw within each plot was performed manually using rakes and forks. The same procedures of straw removal were repeated annually upon harvest of subsequent ratoons. Four straw removal rates were established (total-TR, high-HR, low-LR and no removal-NR) in seven experiments, while three treatments (TR, HR and NR) were established in the other three experiments. Information on the exact amount of straw maintained on the field in each treatment, site and year are presented in Table 3.

Since the experimental groups correspond to distinct straw removal rates, we have grouped the treatments for analysis purposes as follows: NR (all straw left on soil surface), LR (from 25 to $33 \%$ removal), HR (from 50 to $66 \%$ removal) and TR (no straw on the soil - bare soil). In all field experiments, an annual sugarcane fertilization of $120 \mathrm{~kg} \mathrm{ha}^{-1}$ of nitrogen (ammonium nitrate) and $120 \mathrm{~kg} \mathrm{ha}^{-1}$ potassium (potassium chloride) were applied in all plots and none of organic amendments such as filter cake and vinasse were used. Fungicides, insecticides and herbicides were applied in all plots uniformly according to the management strategies established by each sugarcane mill.

Soil sampling and measurements

Sampling campaigns for SOC quantification were performed at the beginning of the experimental period (baseline) in all experimental sites and after two years of straw removal (sites 1, 5, 6 and 7) and four years for the remainder areas (sites 2, 3, 4, 8, 9 and 10). Composite soil samples were collected from the crop row and inter-row positions at the 0-5, 5-10, 10-20 and 20-30 cm depths. Soil samples were air-dried at 35 ${ }^{\circ} \mathrm{C}$ for seven days. After air-drying and gentle grinding, soil samples were sieved through a 2-mm sieve and $10 \mathrm{~g}$ of each sample was finely ground and sieved through a $0.150-\mathrm{mm}$ sieve for measurements of the total C concentration (in duplicate) by dry combustion using the Carbon Analyzer - LECO CN 628 (Nelson \& Sommers, 1996).

\subsection{Calculation of SOC stocks and annual rates of SOC loss/accumulation}

SOC stocks were calculated for all soil depths $(0-5,5-10,10-20$ and 20-30 cm) by multiplying the C concentration by the bulk density and the layer thickness. Additionally, SOC stocks for the 0-10 and 0-30 cm layers were calculated as the sum of the stocks for each sampled depth. Because samples were collected from fixed layers, the SOC stock was adjusted for changes in bulk density that occurred after soil management. Therefore, the methodology described in Ellert \& Bettany (1995) was used to adjust SOC stocks to an equivalent soil mass in comparison with the baseline scenario (before experiment installation).

The annual rates of SOC accumulation or loss $\left(\mathrm{Mg} \mathrm{ha}^{-1} \mathrm{year}^{-1}\right)$ were calculated considering two times horizons. First, it was calculated the difference between SOC stocks of the treatments (NR, LR, HR and TR) relative to baseline, which represents the effects of sugarcane cultivation on SOC stocks regardless of straw removal treatments. Second, the annual rates of SOC accumulation or loss were calculated considering the difference between SOC stocks of NR treatment (business as usual scenario in Brazil) and the treatments of straw removal (LR, HR and TR). In this last case, the differences represent the isolated effect of straw removal on SOC stocks.

Regression models using the relationship between [?]SOC $\left(\mathrm{SOC}_{\text {final }}-\mathrm{SOC}_{\text {initial }}\right)$ as a function of sugarcane straw biomass inputs were performed to estimate the minimum amount of straw $\left(\mathrm{Mg} \mathrm{ha}^{-1} \mathrm{year}^{-1}\right)$ needed to sustain SOC losses (when $\mathrm{y}=0$ ). For the sites 7,8 and 10, the relationship between [?]SOC and C inputs was not significant, and therefore, the minimum amount of straw to maintain SOC stock cannot be determined. For sandy soils (sites 3, 4, 6), where negative slopes with positive corresponding x-intercept were found, the minimum amount of straw was much higher than the productive potential capacity of these sites and, consequently, it was not possible to approximate a realistic minimum amount of sugarcane straw to maintain SOC stock.

Data analyzes

Statistical analysis of data from each site was performed according to a randomized block design, and analysis of variance (ANOVA) was used to test the effects of straw removal on SOC stocks. Data normality 
was confirmed by the Shapiro-Wilk test at $5 \%$ significance, and data transformations were not necessary to meet ANOVA assumptions. When statistically significant ( $\mathrm{F}$ test; $\mathrm{p}<0.05)$, the average values of SOC stocks were compared between treatments by Tukey's test $(p<0.05)$ and by Dunnett's test $(p<0.05)$ for comparison with baseline. Regression analyzes were also performed to explore the relationships between SOC stock changes and cumulative straw inputs for consecutive years. All statistical analyzes were performed using R software (R Development Core Team, 2019).

\section{Results}

\subsection{Sugarcane cultivation effects on SOC stocks}

Our findings indicate that sugarcane production, regardless soil type, substantially affected SOC stocks (Table 4 and Fig. 2A). Compared with baseline scenario, sugarcane production, on average, reduced SOC stocks in the $30 \mathrm{~cm}$ by $3.9 \mathrm{Mg} \mathrm{ha}^{-1}$ in sandy soil and increased in SOC stocks of $4.9 \mathrm{Mg} \mathrm{ha}^{-1}$ in clayey soils. The data revealed that sandy soils under sugarcane cultivation without straw management are losing SOC at mean rate of $-1.8 \mathrm{Mg} \mathrm{ha}^{-1} \mathrm{yr}^{-1}$ in the $0-30 \mathrm{~cm}$ depth. So, results showed that even with all straw maintained on the soil surface (NR treatment), SOC stocks were significantly reduced by $-1.4 \mathrm{Mg} \mathrm{ha}^{-1} \mathrm{yr}^{-1}$ in the sandy areas.

Different responses in SOC stocks were observed in clayey soils, indicating a clear pattern of SOC accumulation for all areas with straw maintenance in the field (Table 3, Fig. 2A). Our results showed that two of the four clayey soils (sites 9 and 10) under sugarcane cultivation without straw management had significant SOC accretion in the 0-10 $\mathrm{cm}$ depth (mean of $4.5 \mathrm{Mg} \mathrm{ha}^{-1}$ ) relative to baseline (Table 4). In the 0-30 $\mathrm{cm}$ depth, even though SOC changes were not statistically significant $(\mathrm{p}<0.05)$, average SOC accumulation rates were

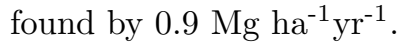

\subsection{Straw removal effects on SOC stocks}

Overall, straw removal induced significant SOC stock depletions and the effects were more evident in the topsoil $(0-10 \mathrm{~cm})$ for sites $1,2,4,8$ and 9 . In the 0-30 cm layer, SOC stocks were reduced for the sites 2,4 and 9, but no changes were detected for the sites 3, 5,6,7 and 10 (Table 4).

Sandy soils were severely susceptible to C losses induced by straw removal (Table S1, Table 4). In site 1, TR treatment (10.6 $\mathrm{Mg} \mathrm{ha}^{-1}$ ) depleted SOC stocks by $18 \%$ in the $0-10 \mathrm{~cm}$ layer compared to $\mathrm{NR}$ (13 Mg $\mathrm{ha}^{-1}$ ), which in turn did not differ from LR and HR. After four consecutive years of straw removal, the effects were even more intense in site 2, where LR, HR and TR induced SOC depletions $(0-10 \mathrm{~cm})$ ranging from 18 to $48 \%$ compared to NR. Similarly, HR and TR treatments in site 4 reduced SOC stocks from $6 \%$ to $21 \%$ compared to NR. In the 0-30 cm layer, sites 2 and 4 presented SOC reductions from 16 to $29 \%$ only for TR relative to NR treatment. Considering only the sandy sites in which differences between treatments were significant in the $0-30 \mathrm{~cm}$ (sites 1, 2 and 4), the data show that straw removal resulted in SOC losses by -0.2 to $-0.9 \mathrm{Mg} \mathrm{ha}{ }^{-1}$ year $^{-1}$ compared to NR treatment (Fig. 2B).

Sugarcane straw removal also depleted SOC stocks in clayey soils (Table S1, Table 4). The impacts of straw removal on SOC stocks were also significant for both layers after four years of evaluation (Table 4), where SOC stock reductions were directly proportional to the increase in straw removal rates $(\mathrm{p}<0.05)$. Increasing rates of straw removal reduced SOC stocks in the $0-10 \mathrm{~cm}$ layer for the sites 8 and 9 . In site 8 , decreases in SOC stock (13\%) was observed in the TR (31.0 $\left.\mathrm{Mg} \mathrm{ha}^{-1}\right)$ compared to NR (39.3 $\left.\mathrm{Mg} \mathrm{ha}^{-1}\right)$. In site 9, the HR (27.2 Mg ha-1) and TR (26.8 $\left.\mathrm{Mg} \mathrm{ha}^{-1}\right)$ treatments reduced SOC stocks in the 0-10 $\mathrm{cm}$ by about $16 \%$ compared to NR (32.3 $\left.\mathrm{Mg} \mathrm{ha}^{-1}\right)$. SOC depletion in the $0-30 \mathrm{~cm}$ was up to $11 \%$ when all straw was removed from the soil (TR-66 $\mathrm{Mg} \mathrm{ha}^{-1}$ ) relative to NR treatment $\left(73.9 \mathrm{Mg} \mathrm{ha}^{-1}\right)$. Annual SOC losses in the 0-30 $\mathrm{cm}$ presented similar magnitudes to those values observed for sandy soils, ranging from 0.5 to $1.0 \mathrm{Mg} \mathrm{ha}^{-1} \mathrm{year}^{-1}$ (Fig. 2B).

3.3 Relationship between cumulative straw inputs and SOC retention

Soil C stocks increased linearly as a function of the accumulated amount of straw added to the soil over the 
evaluated period (Fig. 3). On average, the data show that $85 \mathrm{~kg} \mathrm{C} \mathrm{ha}^{-1}$ were retained in sandy soils for each megagram $(\mathrm{Mg})$ of straw left in the field, but the data ranged from 26 to $144 \mathrm{~kg} \mathrm{C}^{-1}$. Clayey soils showed averaged $\mathrm{C}$ retention of $109 \mathrm{~kg} \mathrm{C} \mathrm{ha}^{-1}$ for each $\mathrm{Mg}$ of dry matter straw in the field, varying from 91 to $134 \mathrm{~kg} \mathrm{C} \mathrm{ha}^{-1}$. Only in three out of ten evaluated sites was possible to quantify the minimum amount of straw required to maintain SOC stocks $(\mathrm{y}=0)$ (Fig. S1). The relationship between [?]SOC and straw biomass inputs showed an estimated quantity of straw on the soil surface of 16,12 and $8 \mathrm{Mg} \mathrm{ha}^{-1} \mathrm{year}^{-1}$ for sites 1,2 and 9 , respectively.

\section{Discussion}

\subsection{Implications of sugarcane cultivation for SOC stocks}

What happened with SOC stocks in sugarcane areas under green harvesting system in south-central Brazil? Answer this question by robust data from field experimentation is fundamental to provide scientific basis for public and sectorial policies discussions related to the sustainability of bioenergy production system. Experimental evidences from this study showed a strong influence of soil texture on SOC changes over time. On average, sugarcane cultivation resulted in $\mathrm{C}$ credit in clayey soils and $\mathrm{C}$ debt in sandy soils (Fig. 2A). Regardless of straw management, the data clearly showed that coarse-textured soils were highly susceptible to SOC losses under sugarcane cultivation, indicating a mean rate of $-1.8 \mathrm{Mg} \mathrm{C} \mathrm{ha}^{-1}$ year ${ }^{-1}$. Conversely, clayey soils accumulated SOC over time independently of straw removal, with a mean accumulation rate of $0.9 \mathrm{Mg} \mathrm{C} \mathrm{ha-1}$ year $^{-1}$.

Studies under tropical and subtropical conditions have reported that fine-textured soils are less susceptible to SOC losses in cropping systems (Dieckow et al., 2009). This pattern can be attributed to the mechanisms that govern the stability of $\mathrm{C}$, such as the high sorption capacity of mineral surfaces in clayey soils. The strong interactions with clay fractions stabilize organic-C compounds, preserving them against decomposition (Dignac et al., 2017; Kopittke et al., 2020; Spohn, 2020). Likewise, greater specific surface area of clayey soil matrix and more complex pores network increase aggregate-protected $\mathrm{C}$ substrates by physical inaccessibility to degradation (Kravchenko et al., 2019). The organo-mineral interactions between C compounds and sand fractions are recognized as weak (Dieckow et al., 2009; Neufeldt et al., 2002), which may explain the significant SOC losses induced by sugarcane cultivation in sandy soils. Our results indicate that the most common scenario of sugarcane production in Brazil, based on green mechanized harvesting (all straw maintained in the field), monoculture and conventional tillage during the replanting periods, was not able to sustain SOC stocks in sandy soils.

Additionally, the lower SOC stocks in sandy soils can be associated with sugarcane productive potential of these areas. For example, Carvalho et al. (2019) measured sugarcane yields in the same experimental areas and concluded that sandy soils produce $40 \%$ less biomass than clayey soils. The authors reported that the higher yields in clayey soils are linked to greater water availability and soil fertility, thus providing proper conditions for root growth and development. Since roots and exudates are important inputs of C to the soil in sugarcane fields (Carvalho et al., 2013), the contribution of root compartments to SOC stocks is likely to be lower in sandy soils relative to clayey soils.

It is noteworthy that conventional tillage was carried out during sugarcane renovation for all areas of this study. Intensive soil tillage during sugarcane renovation exposes SOC that is protected by aggregates and make it available for microbial use, thus causing SOC losses by inducing $\mathrm{CO}_{2}$ emissions releases to the atmosphere (Silva-Olaya et al., 2013). According to La Scala et al. (2006), conventional tillage during sugarcane renovation increased soil $\mathrm{CO}_{2}$ emissions by $8.4 \mathrm{Mg}^{-1}$ relative to no-tillage system. Similarly, Segnini et al. (2013) reported that most part of the SOC accumulated along the sugarcane crop cycle could be lost during the renovation period under conventional tillage, and Cerri et al. (2011) mentioned that such $\mathrm{C}$ losses are higher in sandy soils. Conversely, many studies have indicated that the adoption of reduced tillage could be a feasible strategy to avoid not only SOC losses during the renovation periods (Segnini et al., 2013; Tenelli et al., 2019), but also to increase the capacity of sugarcane soils to accumulate C over time. Alternative strategies to avoid SOC depletions in sugarcane fields include the implementation of crop 
rotation in the sugarcane reform period, as well as the application of organic amendments such as filter cake, vinasse and biochar (Bordonal et al., 2018).

As important as implementing a set of management practices to avoid SOC losses, the selection of the appropriate soil type is crucial to enhance SOC sequestration in sugarcane cropping systems. In clayey soils, the rates of SOC accumulation at the $0-30 \mathrm{~cm}$ ranged between 0.9 and $2.5 \%$ per year, demonstrating that the cultivation of sugarcane in this soil type is a realistic opportunity to reach values of $\mathrm{C}$ accretion even above the global targets of $0.4 \%$ per year (" 4 per 1000" Initiative - www.4p1000.org) launched by the France government at the COP 21 held in Paris (Minasny et al., 2017). On the other hand, the proportions of SOC losses in sandy areas were quite contrasting relative to clayey-textured soils, showing negative rates from $-3.4 \%$ to $-7.3 \%$, and consequently suggesting how challenging is to integrate sandy soils (marginal lands) into a productive bioenergy system in a sustainable way. Over again, it is imperative to establish guidelines for adopting sustainable soil management in sandy soils under sugarcane land-use to reduce (even partially) $\mathrm{C}$ losses over time. This study indicates that the SOC accumulation found in clayey soils proves to be a sustainable strategy to sustain $\mathrm{C}$ into the soil, thus helping the Brazilian sector to reduce $\mathrm{CO}_{2}$ emissions to the atmosphere and comply with the targets of the 2030 agenda for sustainable development proposed by the United Nations (www.un.org/sustainabledevelopment).

\subsection{Straw removal impacts on SOC stocks}

Sugarcane-based biofuels stand out as a good solution to reduce the dependence on fossil fuels, ensure energy security and mitigate greenhouse gas (GHG) emissions compared to other energy crops such as maize and sugar beet (Goldemberg \& Guardabassi, 2010). In this sense, it is not clear thus far the extent to which the impact of crop residues removal on SOC stocks could be offset by the avoided GHG emissions of bioenergy production (e.g., cellulosic ethanol or electricity) in substitution of fossil fuel sources.

Covering ten experimental sites across the main growing sugarcane region in Brazil, which concentrates 90\% of national and $36 \%$ of global production, this study provides the most complete and robust datasets about the impact of straw removal on SOC stock changes. For excessive straw removal rates (TR and HR), the SOC stocks $(0-30 \mathrm{~cm})$ were depleted in most areas, indicating decreases in SOC stock relative to the most common scenario of sugarcane production in Brazil (NR treatment). SOC losses were proportional to the increase of straw removal rates. Results of this study are consistent with previous long-term predictions obtained from modelling research conducted in Brazil (Carvalho et al., 2017b; Oliveira et al., 2017), and are in line with SOC declines reported in sites with corn stover removal around world (Johnson et al., 2014; Xu et al., 2019). Aligned with our findings, recent studies have shown that the maintenance of sugarcane straw on soil surface provides several soil ecosystem services, such as protection against soil erosion (Carvalho et al., 2017), favorable environment to microbiological processes (Pimentel et al., 2019; Tenelli et al., 2019), stabilization of aggregates (Castioni et al., 2019), nutrients cycling and reduction of fertilizer consumption (Cherubin et al., 2019), all of which having essential role to boost sugarcane crop yield (Carvalho et al., 2019).

By the way, what was the role of straw for each removal treatment? Considering all $\mathrm{C}$ added via straw, how much of this $\mathrm{C}$ was retained into the soil? Assuming that sugarcane straw has $440 \mathrm{~g} \mathrm{~kg}^{-1}$ of $\mathrm{C}$ content in dry matter (Menandro et al., 2017), our results suggested that $19 \%$ and $25 \%$ of the $\mathrm{C}$ added via straw was retained into the soil of the sandy and clayey sites, respectively. These values are even higher than those found in the literature for sugarcane and other crop residues, which usually ranges from 6 to 15\% (Bolinder et al., 1999; Robertson \& Thorburn, 2007; Sousa Junior et al., 2018). For example, Robertson and Thorburn (2007) observed that $13 \%$ of C input via sugarcane straw was accumulated in the soil after five years of straw maintenance in Australia.

Based on the regression of cumulative straw returns against to measured SOC, clayey soils required 8.06 $\mathrm{Mg} \mathrm{ha} \mathrm{yr}^{-1}$ of straw to sustain SOC stocks, while an amount varying from 11.0 to $16.3 \mathrm{Mg} \mathrm{ha}^{-1} \mathrm{yr}^{-1}$ was necessary for sandy soils. But these results revealed that only one site of clayey areas and two of sandy areas presented a linear relationship between $\triangle \mathrm{SOC}$ and straw additions (Fig. S1). Differently from our 
conditions, Johnson et al., (2014) observed a minimum corn stover amount of $6.38 \mathrm{Mg} \mathrm{ha}^{-1} \mathrm{yr}^{-1}$ necessary to maintain SOC stocks in the soils of Corn Belt USA, where the soil was described to be close to C saturation. The conceptual approach to estimate SOC changes used by Johnson et al. (2014) did not fit very well for this study. For instance, the y-intercept of the regression equation was higher than zero in clayey areas, which means that soil $\mathrm{C}$ stocks were maintained even with complete removal of straw. This lack of negative effect of straw removal in clayey soils can be attributed to other sources of C inputs (e.g., roots, exudates), which may have been sufficient to sustain SOC stocks due to the protection of SOC by interactions with clay particles (Dignac et al., 2017). In sandy soils, the absence of response is likely related to the low capacity of these soils to accumulate $\mathrm{C}$, showing that the minimum amount of sugarcane straw to sustain SOC was so high and far away from what those areas could potentially produce because of their limited conditions.

This study highlights that straw-derived bioenergy is not "zero impact" in terms of C budget, since it directly affects soil C stocks. Regardless of whether SOC stocks are increasing (clayey soils) or decreasing (sandy soils) in comparison with baseline as already discussed in section 4.1, our findings reinforce the role of straw as a primary source of $\mathrm{C}$ to the soil and indicate that straw removal tends to reduce SOC stocks. In order to have bioenergy production in an environmentally compatible manner, the benefits of biofuels produced from crop residues must compensate potential SOC losses.

Since sandy soils are more vulnerable environments and present difficult in accumulate or maintain SOC stocks, this study raises the following question: Can sandy areas really be subject of straw removal projects? The data clearly endorse that it would not be sustainable considering the current management system of sugarcane production. It is important the mention that the large-scale use of sandy soils for sugarcane production in south-central Brazil occurred mainly in the past 15 years, when a large expansion of sugarcane plantation occurred in the country. Based on that, the SOC stocks changes induced crop residues retention in these soils are poorly understood, and more comprehensive studies should be encouraged.

This study shows that the straw retention is crucial to reduce SOC losses in sandy soils managed conventionally in sugarcane cropping systems and alternative management such as no-tillage practices, crop rotation and organic amendments could offer a climate-smart solution to ensure food security and sustain soil productivity (Zhao et al., 2020). For example, Tenelli et al. (2019) concluded that the adoption of reduced tillage offsets C losses induced by straw removal, and consequently, greater amount of sugarcane straw can be sustainably removed from high productive fields without depleting SOC stocks. SOC stock changes are driven by a variety of processes that are interconnected, and therefore, determining how much straw is needed to maintain SOC stock levels for a sustainable bioenergy production using short- and medium-term empirical data is still challenging. The establishment of critical levels of straw removal at site/farm or regional scale should vary according to the site specificity of soil, climate and management strategies. In order to estimate the influence of each factor on SOC stocks, simulation models can be a useful approach to assess critical levels of straw mulching and predict these impacts on a long-term basis, which is a key aspect when it comes to SOC dynamics. Lastly, we advocate that the inclusion of SOC stocks changes in life-cycle assessments is mandatory and should be encouraged considering scenarios of straw removal in areas of clayey and sandy soils for a more credible GHG balance of sugarcane straw-derived bioenergy.

\section{Conclusions}

The new biomass-based bioenergy context raises concerns about the effects of indiscriminate rates of straw removal on SOC stocks and sustainability of sugarcane production system. This study indicates that excessive rates of straw removal are impairing SOC stocks, suggesting that sustainable straw management must be adopted to prevent additional soil degradation and a GHG unbalance in the future for bioenergy production. Our findings showed strong SOC depletion in sandy soils regardless of the amount of straw left in the field. On the other hand, clayey soils exhibited SOC accumulation over time, even removing all the straw from the soil surface.

In this context, the removal of sugarcane straw for bioenergy production (i.e., cellulosic ethanol or bioelectricity) in Brazil may be advantageous from an energy security point of view, but should be avoided in 
sandy areas because it reduces SOC from a naturally infertile soil and decreases sugarcane yield, which is already low under these conditions. We advocate that the use of crop residues for bioenergy production in Brazil should not deplete SOC stocks, since tropical soils are characterized by low SOC levels and favorable environment for rapid decomposition processes of SOC.

\section{References}

Bolinder, M. A., Angers, D. A., Giroux, M., \& Laverdière, M. R. (1999). Estimating C inputs retained as soil organic matter from corn (Zea Mays L.). Plant and Soil , 215 (1), 85-91. https://doi.org/10.1023/A:1004765024519

Bordonal, R. de O., Carvalho, J. L. N., Lal, R., de Figueiredo, E. B., de Oliveira, B. G., \& La Scala, N. (2018). Sustainability of sugarcane production in Brazil. A review. Agronomy for Sustainable Development , 38 (2). https://doi.org/10.1007/s13593-018-0490-x

Bordonal, R. de O., Menandro, L. M. S., Barbosa, L. C., Lal, R., Milori, D. M. B. P., Kolln, O. T., ... Carvalho, J. L. N. (2018). Sugarcane yield and soil carbon response to straw removal in south-central Brazil.Geoderma , 328 , 79-90. https://doi.org/10.1016/j.geoderma.2018.05.003

Carvalho, João Luís Nunes, Nogueirol, R. C., Menandro, L. M. S., Bordonal, R. de O., Borges, C. D., Cantarella, H., \& Franco, H. C. J. (2017). Agronomic and environmental implications of sugarcane straw removal: a major review. GCB Bioenergy , 9 (7), 1181-1195. https://doi.org/10.1111/gcbb.12410

Carvalho, João Luís Nunes, Menandro, L. M. S., de Castro, S. G. Q., Cherubin, M. R., Bordonal, R. de O., Barbosa, L. C., .. Castioni, G. A. F. (2019). Multilocation Straw Removal Effects on Sugarcane Yield in South-Central Brazil. Bioenergy Research . https://doi.org/10.1007/s12155-019-10007-8

Carvalho, Joao L.N., Hudiburg, T. W., Franco, H. C. J., \& DeLucia, E. H. (2017). Contribution of above- and belowground bioenergy crop residues to soil carbon. GCB Bioenergy , 9 (8), 1333-1343. https://doi.org/10.1111/gcbb.12411

Carvalho, João Luís Nunes, Otto, R., Franco, H. C. J., \& Trivelin, P. C. O. (2013). Input of sugarcane post-harvest residues into the soil.Scientia Agricola , 70 (5), 336-344. https://doi.org/10.1590/S010390162013000500008

Castioni, G. A. F., Cherubin, M. R., Bordonal, R. de O., Barbosa, L. C., Menandro, L. M. S., \& Carvalho, J. L. N. (2019). Straw Removal Affects Soil Physical Quality and Sugarcane Yield in Brazil. Bioenergy Research , 789-800. https://doi.org/10.1007/s12155-019-10000-1

Cerri, C. C., Galdos, M. V., Maia, S. M. F., Bernoux, M., Feigl, B. J., Powlson, D., \& Cerri, C. E. P. (2011). Effect of sugarcane harvesting systems on soil carbon stocks in Brazil: An examination of existing data. European Journal of Soil Science, 62 (1), 23-28. https://doi.org/10.1111/j.1365-2389.2010.01315.x

Cherubin, M. R., Lisboa, I. P., Silva, A. G. B., Varanda, L. L., Bordonal, R. O., Carvalho, J. L. N., .. Cerri, C. E. P. (2019). Sugarcane Straw Removal: Implications to Soil Fertility and Fertilizer Demand in Brazil. BioEnergy Research . https://doi.org/10.1007/s12155-019-10021-w

Companhia Nacional de Abastecimento - CONAB. (2019).ACOMPANHAMENTO DA SAFRA BRASILEIRA Cana-de-açúcar - Safra 2019/20, n.2 - Segundo levantamento . Brasília.

Dieckow, J., Bayer, C., Conceição, P. C., Zanatta, J. A., Martin-Neto, L., Milori, D. B. M., ... Hernani, L. C. (2009). Land use, tillage, texture and organic matter stock and composition in tropical and subtropical Brazilian soils. European Journal of Soil Science ,60 (2), 240-249. https://doi.org/10.1111/j.13652389.2008.01101.x

Dignac, M.-F., Derrien, D., Barré, P., Barot, S., Cécillon, L., Chenu, C., .. Basile-Doelsch, I. (2017). Increasing soil carbon storage: mechanisms, effects of agricultural practices and proxies. A review.Agronomy for Sustainable Development , 37 (2), 14. https://doi.org/10.1007/s13593-017-0421-2 
Ellert, B. H., \& Bettany, J. R. (1995). Calculation of organic matter and nutrients stored in soils under contrasting management regimes.Canadian Journal of Soil Science , 75 (4), 529-538. https://doi.org/10.4141/cjss95-075

FAO. (2019). Recarbonization of global soils . Retrieved from http://doi.wiley.com/10.2136/sssabookser5.3.c34

Goldemberg, J., \& Guardabassi, P. (2010). The potential for first-generation ethanol production from sugarcane. Biofuels, Bioproducts and Biorefining , 4 (1), 17-24. https://doi.org/10.1002/bbb.186

Ipcc, A., \& Report, S. (2019). Climate Change and Land - IPCC Special Report on Climate Change, Desertification, Land Degradation, Sustainable Land Management, Food Security, and Greenhouse gas fluxes in Terrestrial Ecosystems .

Johnson, J. M. F., Novak, J. M., Varvel, G. E., Stott, D. E., Osborne, S. L., Karlen, D. L., .. Adler, P. R. (2014). Crop Residue Mass Needed to Maintain Soil Organic Carbon Levels: Can It Be Determined? Bioenergy Research , 7 (2), 481-490. https://doi.org/10.1007/s12155-013-9402-8

Kopittke, P. M., Dalal, R. C., Hoeschen, C., Li, C., Menzies, N. W., \& Mueller, C. W. (2020). Soil organic matter is stabilized by organo-mineral associations through two key processes: The role of the carbon to nitrogen ratio. Geoderma , 357 (June 2019), 113974. https://doi.org/10.1016/j.geoderma.2019.113974

Kravchenko, A. N., Guber, A. K., Razavi, B. S., Koestel, J., Quigley, M. Y., Robertson, G. P., \& Kuzyakov, Y. (2019). Microbial spatial footprint as a driver of soil carbon stabilization. Nature Communications , 10 (1), 1-10. https://doi.org/10.1038/s41467-019-11057-4

La Scala, N., Bolonhezi, D., \& Pereira, G. T. (2006). Short-term soil CO2 emission after conventional and reduced tillage of a no-till sugar cane area in southern Brazil. Handbook of Environmental Chemistry, Volume 5: Water Pollution, 91 (1-2), 244-248. https://doi.org/10.1016/j.still.2005.11.012

Lal, R. (2004). Soil carbon sequestration impacts on global climate change and food security. Science , 304 (5677), 1623-1627. https://doi.org/10.1126/science.1097396

Lorenz, K., Lal, R., \& Ehlers, K. (2019). Soil organic carbon stock as an indicator for monitoring land and soil degradation in relation to United Nations' Sustainable Development Goals. Land Degradation and Development , 30 (7), 824-838. https://doi.org/10.1002/ldr.3270

Menandro, L. M. S., Cantarella, H., Franco, H. C. J., Kölln, O. T., Pimenta, M. T. B., Sanches, G. M., .. Carvalho, J. L. N. (2017). Comprehensive assessment of sugarcane straw: implications for biomass and bioenergy production. Biofuels, Bioproducts and Biorefining ,11 (3), 488-504. https://doi.org/10.1002/bbb.1760

Minasny, B., Malone, B. P., McBratney, A. B., Angers, D. A., Arrouays, D., Chambers, A., ... Winowiecki, L. (2017). Soil carbon 4 per mille. Geoderma , 292 , 59-86. https://doi.org/10.1016/j.geoderma.2017.01.002

Nelson, D. W., \& Sommers, L.E. (1996). Total Carbon, Organic Carbon, and Organic Matter . Methods of soil analysis. Chapter 34 (5), 961-1010.

Neufeldt, H., Resck, D. V. S., \& Ayarza, M. A. (2002). Texture and land-use effects on soil organic matter in Cerrado Oxisols, Central Brazil. Geoderma , 107 (3-4), 151-164. https://doi.org/10.1016/S00167061(01)00145-8

Oliveira, D. M. S., Williams, S., Cerri, C. E. P., \& Paustian, K. (2017). Predicting soil C changes over sugarcane expansion in Brazil using the DayCent model. GCB Bioenergy , 9 (9), 1436-1446. https://doi.org/10.1111/gcbb.12427

R Development Core Team. (2019). A language and environment for statistical computing. R Foundation for Statistical Computing. Retrieved from https://www.r-project.org/

Robertson, F. A., \& Thorburn, P. J. (2007). Management of sugarcane harvest residues: Consequences for soil carbon and nitrogen.Australian Journal of Soil Research , 45 (1), 13-23. https://doi.org/10.1071/SR06080 
Ruiz Corrêa, S. T., Barbosa, L. C., Menandro, L. M. S., Scarpare, F. V., Reichardt, K., de Moraes, L. O., ... Carvalho, J. L. N. (2019). Straw Removal Effects on Soil Water Dynamics, Soil Temperature, and Sugarcane Yield in South-Central Brazil. Bioenergy Research . https://doi.org/10.1007/s12155-019-09981-w

Sanderman, J., Hengl, T., \& Fiske, G. J. (2017). Soil carbon debt of 12,000 years of human land use . (4), 1-7. https://doi.org/10.1073/pnas.1706103114

Satiro, L. S., Cherubin, M. R., Safanelli, J. L., Lisboa, I. P., Rocha Junior, P. R. da, Cerri, C. E. P., \& Cerri, C. C. (2017). Sugarcane straw removal effects on Ultisols and Oxisols in south-central Brazil.Geoderma Regional , 11 , 86-95. https://doi.org/10.1016/j.geodrs.2017.10.005

Silva-Olaya, A. M., Cerri, C. E. P., La Scala, N., Dias, C. T. S., \& Cerri, C. C. (2013). Carbon dioxide emissions under different soil tillage systems in mechanically harvested sugarcane. Environmental Research Letters , 8 (1). https://doi.org/10.1088/1748-9326/8/1/015014

Sousa Junior, J. G. d. A., Cherubin, M. R., Oliveira, B. G., Cerri, C. E. P., Cerri, C. C., \& Feigl, B. J. (2018). Three-Year Soil Carbon and Nitrogen Responses to Sugarcane Straw Management. Bioenergy Research , 11 (2), 249-261. https://doi.org/10.1007/s12155-017-9892-x

Souza, R. A., Telles, T. S., Machado, W., Hungria, M., Filho, J. T., \& Guimarães, M. de F. (2012). Effects of sugarcane harvesting with burning on the chemical and microbiological properties of the soil.Agriculture, Ecosystems and Environment , 155 , 1-6. https://doi.org/10.1016/j.agee.2012.03.012

Spohn, M. (2020). Phosphorus and carbon in soil particle size fractions: A synthesis. Biogeochemistry , 147 (3), 225-242. https://doi.org/10.1007/s10533-019-00633-x

Tenelli, S., de Oliveira Bordonal, R., Barbosa, L. C., \& Carvalho, J. L. N. (2019). Can reduced tillage sustain sugarcane yield and soil carbon if straw is removed? Bioenergy Research . https://doi.org/10.1007/s12155019-09996-3

Thornthwaite, C. W. (1948). An Approach toward a Rational Classification of Climate. Geographical Review , 38 (1), 55-94. https://doi.org/10.2307/210739

Vermeulen, S., Bossio, D., Lehmann, J., Luu, P., Paustian, K., Webb, C., .. Warnken, M. (2019). A global agenda for collective action on soil carbon. Nature Sustainability , 2 (1), 2-4. https://doi.org/10.1038/s41893018-0212-z

Xu, H., Sieverding, H., Kwon, H., Clay, D., Stewart, C., Johnson, J. M. F., .. Wang, M. (2019). A global meta-analysis of soil organic carbon response to corn stover removal. GCB Bioenergy ,11 (10), 1215-1233. https://doi.org/10.1111/gcbb.12631

Zhao, X., Liu, B-Y., Liu, S-L, L., Qi, J-Y., Wang, X., Chao, P., Li, S-S., Zhang, X-Z., Yang, X-G., Lal, R., Chen, F. \& Zhang, H-L. (2020). Sustaining crop production in China's cropland by crop residue retention: A meta-analysis. Land Degrad Dev. , 31, 694- 709. https://doi.org/10.1002/ldr.3492

TABLES

Table 1. Descriptions of the research sites.

\begin{tabular}{|c|c|c|c|c|c|c|c|c|c|}
\hline $\begin{array}{l}\text { Soil } \\
\text { type }\end{array}$ & $\begin{array}{l}\text { Sandy } \\
\text { soils }\end{array}$ & $\begin{array}{l}\text { Sandy } \\
\text { soils }\end{array}$ & $\begin{array}{l}\text { Sandy } \\
\text { soils }\end{array}$ & $\begin{array}{l}\text { Sandy } \\
\text { soils }\end{array}$ & $\begin{array}{l}\text { Sandy } \\
\text { soils }\end{array}$ & $\begin{array}{l}\text { Sandy } \\
\text { soils }\end{array}$ & $\begin{array}{l}\text { Clayey } \\
\text { soils }\end{array}$ & $\begin{array}{l}\text { Clayey } \\
\text { soils }\end{array}$ & $\begin{array}{l}\text { Clayey } \\
\text { soils }\end{array}$ \\
\hline$u$ & (Site 1) & (Site 2) & (Site : & (Site & (Site & $\begin{array}{l}\text { olsilirinópol } \\
\text { (Site 6) }\end{array}$ & (Site 7) & (Site 8) & (Site 9) \\
\hline
\end{tabular}




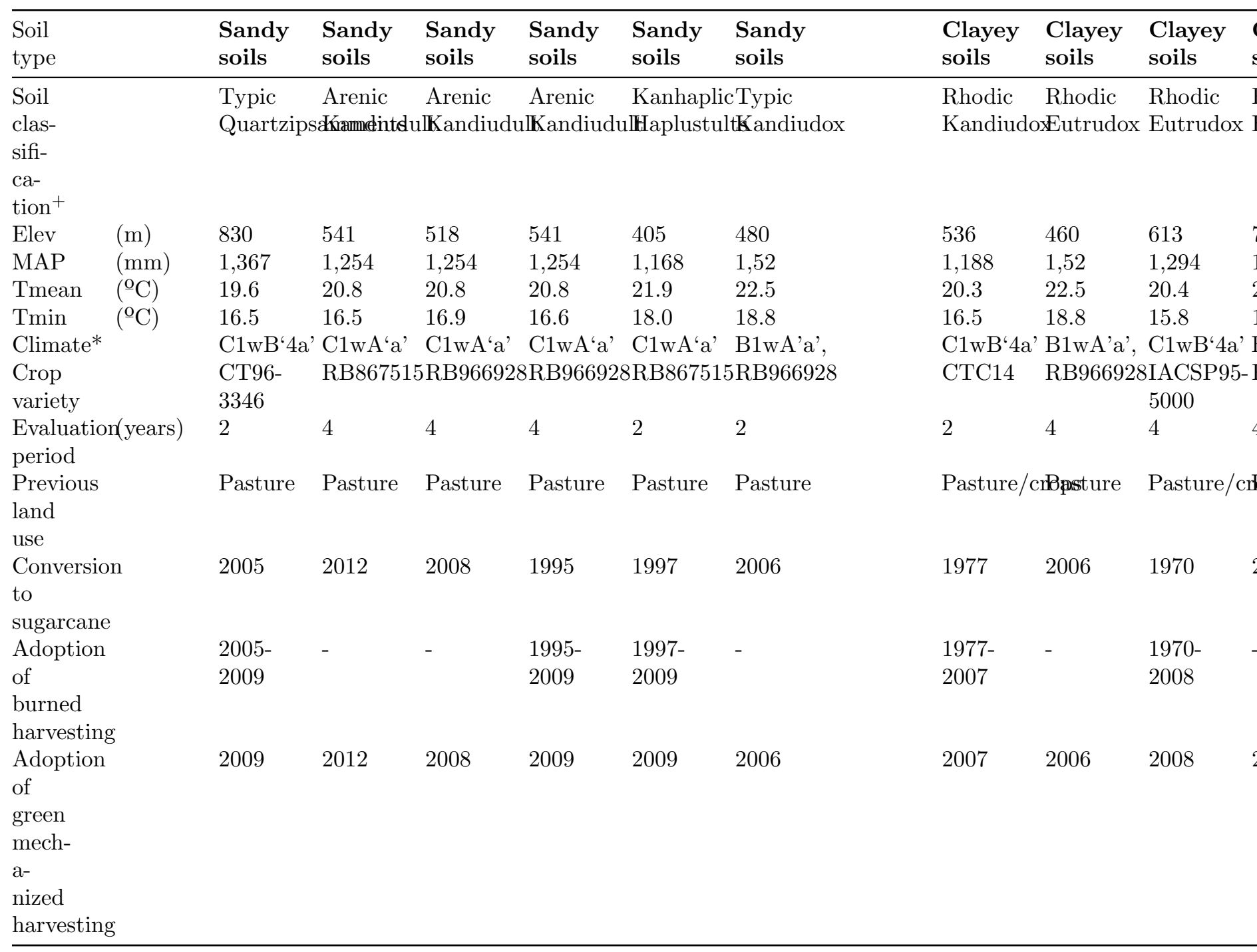

*(Thornthwaite, 1948); ${ }^{+}$USDA-Soil Taxonomy (Soil Survey Staff, 2014)

\begin{tabular}{|c|c|c|c|c|c|c|c|c|c|}
\hline $\begin{array}{l}\text { Soil } \\
\text { properties }\end{array}$ & $\begin{array}{l}\text { Sandy } \\
\text { soils }\end{array}$ & $\begin{array}{l}\text { Sandy } \\
\text { soils }\end{array}$ & $\begin{array}{l}\text { Sandy } \\
\text { soils }\end{array}$ & $\begin{array}{l}\text { Sandy } \\
\text { soils }\end{array}$ & $\begin{array}{l}\text { Sandy } \\
\text { soils }\end{array}$ & $\begin{array}{l}\text { Sandy } \\
\text { soils }\end{array}$ & $\begin{array}{l}\text { Clayey } \\
\text { soils }\end{array}$ & $\begin{array}{l}\text { Clayey } \\
\text { soils }\end{array}$ & $\begin{array}{l}\text { Clayey } \\
\text { soils }\end{array}$ \\
\hline Units & $\begin{array}{l}\text { Itirapina } \\
\text { (Site 1) }\end{array}$ & $\begin{array}{l}\text { Spuatá/S } \\
\text { (Site 2) }\end{array}$ & $\begin{array}{l}\text { PQuatá/S } \\
\text { (Site 3) }\end{array}$ & $\begin{array}{l}\text { PQuatá/S } \\
\text { (Site 4) }\end{array}$ & $\begin{array}{l}\text { PValparaí } \\
\text { (Site 5) }\end{array}$ & $\begin{array}{l}\text { o(sillininópolis/GO } \\
\text { (Site 6) }\end{array}$ & $\begin{array}{l}\text { Capivari } \\
\text { (Site 7) }\end{array}$ & $\begin{array}{l}\text { SQQuirinóp } \\
\text { (Site 8) }\end{array}$ & 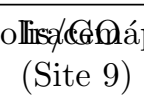 \\
\hline
\end{tabular}

\begin{tabular}{|c|c|c|c|c|c|c|c|c|c|}
\hline $\begin{array}{l}\mathrm{pH} \\
\mathrm{CaCl}_{2}\end{array}$ & & 5.5 & 4.8 & 5.4 & 5.0 & 4.8 & 5.9 & 4.8 & 5.5 \\
\hline $\mathrm{C}$ & $\begin{array}{l}(\mathrm{g} \\
\left.\mathrm{kg}^{-1}\right)\end{array}$ & 6.1 & 4.2 & 4.9 & 5.0 & 5.7 & 9.3 & 11.2 & 17.9 \\
\hline $\mathrm{P}$ & $\begin{array}{l}(\mathrm{mg} \\
\left.\mathrm{dm}^{-3}\right)\end{array}$ & 38 & 16 & 7 & 9 & 15 & 5 & 25 & 8 \\
\hline
\end{tabular}




\begin{tabular}{|c|c|c|c|c|c|c|c|c|c|c|}
\hline \multicolumn{2}{|c|}{$\begin{array}{l}\text { Soil } \\
\text { properties }\end{array}$} & \multirow{2}{*}{$\begin{array}{l}\begin{array}{l}\text { Sandy } \\
\text { soils }\end{array} \\
1.5\end{array}$} & \multirow{2}{*}{$\begin{array}{l}\begin{array}{l}\text { Sandy } \\
\text { soils }\end{array} \\
0.3\end{array}$} & \multirow{2}{*}{$\begin{array}{l}\begin{array}{l}\text { Sandy } \\
\text { soils }\end{array} \\
1.0\end{array}$} & \multirow{2}{*}{$\begin{array}{l}\begin{array}{l}\text { Sandy } \\
\text { soils }\end{array} \\
1.0\end{array}$} & \multirow{2}{*}{$\begin{array}{l}\begin{array}{l}\text { Sandy } \\
\text { soils }\end{array} \\
2.7\end{array}$} & \multirow{2}{*}{$\begin{array}{l}\begin{array}{l}\text { Sandy } \\
\text { soils }\end{array} \\
0.6\end{array}$} & \multirow{2}{*}{$\begin{array}{l}\begin{array}{l}\text { Clayey } \\
\text { soils }\end{array} \\
5.9\end{array}$} & \multirow{2}{*}{$\begin{array}{l}\begin{array}{l}\text { Clayey } \\
\text { soils }\end{array} \\
4.0\end{array}$} & \multirow{2}{*}{$\begin{array}{l}\begin{array}{l}\text { Clayey } \\
\text { soils }\end{array} \\
10.6\end{array}$} \\
\hline$\overline{\mathrm{K}}$ & $\begin{array}{l}(\text { mmolc } \\
\left.\mathrm{dm}^{-3}\right)\end{array}$ & & & & & & & & & \\
\hline $\mathrm{Ca}$ & & 17 & 12 & 34 & 18 & 6 & 17 & 19 & 40 & 54 \\
\hline $\mathrm{Mg}$ & & 9 & 4 & 3 & 7 & 2 & 8 & 5 & 12 & 29 \\
\hline BS & $(\%)$ & 54 & 49 & 79 & 61 & 38 & 61 & 53 & 71 & 65 \\
\hline $\mathrm{BD}$ & $\begin{array}{l}(\mathrm{Mg} \\
\left.\mathrm{m}^{-3}\right)\end{array}$ & 1.64 & 1.70 & 1.68 & 1.75 & 1.57 & 1.77 & 1.33 & 1.30 & 1.38 \\
\hline Sand & $\begin{array}{l}(\mathrm{g} \\
\left.\mathrm{kg}^{-1}\right)\end{array}$ & 923 & 829 & 825 & 807 & 863 & 749 & 603 & 247 & 229 \\
\hline Clay & & 54 & 112 & 111 & 72 & 115 & 226 & 330 & 563 & 602 \\
\hline Silt & & 22 & 59 & 64 & 122 & 22 & 25 & 65 & 190 & 168 \\
\hline
\end{tabular}

Table 2. Soil chemical and physical characterization at the beginning of the field experiments.

Table 3. Amount of straw maintained ( $\mathrm{Mg} \mathrm{ha}^{-1}$ of dry basis) on soil surface based on the straw removal rate established in percentage of total straw production.

\begin{tabular}{|c|c|c|c|}
\hline Sites & Straw removal rate & Amount of straw left on soil surface $\left(\mathrm{Mg} \mathrm{ha}^{-1}\right)$ & Amount of straw left on soil surface \\
\hline & & $1^{\text {st }}$ year & $2^{\text {nd }}$ year \\
\hline \multirow[t]{4}{*}{$1^{*}, 2,3,6^{*}, 9$} & $\mathrm{TR}$ & 0 & 0 \\
\hline & $\mathrm{HR}$ & 5 & 5 \\
\hline & LR & 10 & 10 \\
\hline & NR & 15 & 15 \\
\hline \multirow[t]{3}{*}{4} & $\mathrm{TR}$ & 0 & 0 \\
\hline & $\mathrm{HR}$ & 4.6 & 6.3 \\
\hline & NR & 9.2 & 12.6 \\
\hline \multirow[t]{4}{*}{$5^{*}$} & TR & 0 & 0 \\
\hline & $\mathrm{HR}$ & 5.1 & 4.1 \\
\hline & LR & 11.4 & 9.6 \\
\hline & NR & 15.0 & 12.4 \\
\hline \multirow[t]{4}{*}{$7^{*}$} & TR & 0 & 0 \\
\hline & HR & 3.4 & 3.2 \\
\hline & LR & 13.0 & 11.4 \\
\hline & NR & 16.6 & 14.7 \\
\hline \multirow[t]{3}{*}{8} & TR & 0 & 0 \\
\hline & $\mathrm{HR}$ & 8.3 & 8.6 \\
\hline & NR & 16.5 & 17.2 \\
\hline \multirow[t]{3}{*}{10} & TR & 0 & 0 \\
\hline & HR & 7.5 & 8.0 \\
\hline & NR & 14.9 & 15.9 \\
\hline
\end{tabular}

NR, HR and TR denote no, high and total straw removal rates, respectively. Asterisk (*) symbol on the respective site indicates that straw management was performed up to the second year.

Table 4. SOC stocks $\left(\mathrm{Mg} \mathrm{ha}^{-1}\right)$ to a $30-\mathrm{cm}$ depth in areas under straw removal (TR-total removal, LR-low removal, HR-high removal and NR-no removal) in sandy and clayey soils. 


\begin{tabular}{|c|c|c|c|c|c|c|c|c|c|}
\hline & Sites & Baseline & $\begin{array}{l}\text { Straw } \\
\text { re- } \\
\text { moval } \\
\text { rate }\end{array}$ & $\begin{array}{l}\text { Straw } \\
\text { re- } \\
\text { moval } \\
\text { rate }\end{array}$ & $\begin{array}{l}\text { Straw } \\
\text { re- } \\
\text { moval } \\
\text { rate }\end{array}$ & $\begin{array}{l}\text { Straw } \\
\text { re- } \\
\text { moval } \\
\text { rate }\end{array}$ & $\begin{array}{l}\text { Straw } \\
\text { re- } \\
\text { moval } \\
\text { rate }\end{array}$ & $\begin{array}{l}\text { Straw } \\
\text { re- } \\
\text { moval } \\
\text { rate }\end{array}$ & $\begin{array}{l}\text { Straw } \\
\text { re- } \\
\text { moval } \\
\text { rate }\end{array}$ \\
\hline & & & NR & & LR & & HR & & TR \\
\hline & & $\begin{array}{l}0-10 \\
\mathrm{~cm}\end{array}$ & $\begin{array}{l}0-10 \\
\mathrm{~cm}\end{array}$ & $\begin{array}{l}0-10 \\
\mathrm{~cm}\end{array}$ & $\begin{array}{l}0-10 \\
\mathrm{~cm}\end{array}$ & $\begin{array}{l}0-10 \\
\mathrm{~cm}\end{array}$ & $\begin{array}{l}0-10 \\
\mathrm{~cm}\end{array}$ & $\begin{array}{l}0-10 \\
\mathrm{~cm}\end{array}$ & $\begin{array}{l}0-10 \\
\mathrm{~cm}\end{array}$ \\
\hline \multirow[t]{6}{*}{$\begin{array}{l}\text { Sandy } \\
\text { soils }\end{array}$} & 1 & 12.7 & 13.0 & $\mathrm{a}$ & 12.3 & $a b$ & 11.0 & $a b$ & $10.6^{*}$ \\
\hline & 2 & 7.5 & $12.4^{*}$ & $\mathrm{a}$ & $10.2^{*}$ & $\mathrm{~b}$ & $9.5^{*}$ & $\mathrm{~b}$ & 6.4 \\
\hline & 3 & 10.3 & 8.6 & ns & 8.7 & ns & 8.0 & ns & 8.1 \\
\hline & 4 & 10.2 & 8.7 & $\mathrm{a}$ & - & & 8.2 & $\mathrm{~b}$ & $6.9^{*}$ \\
\hline & 5 & 9.0 & 9.1 & ns & 8.2 & ns & 8.6 & ns & 8.5 \\
\hline & 6 & 17.9 & 16.2 & ns & 16.3 & ns & 15.6 & ns & 14.8 \\
\hline \multirow{5}{*}{$\begin{array}{l}\text { Clayey } \\
\text { soils }\end{array}$} & 7 & 14.8 & 16.5 & $\mathrm{~ns}$ & 15.8 & ns & 15.8 & ns & 15.1 \\
\hline & 8 & 32.4 & 35.7 & $\mathrm{a}$ & - & & 34.1 & $a b$ & 31.0 \\
\hline & 9 & 28.4 & $32.3^{*}$ & $\mathrm{a}$ & 31.1 & $\mathrm{a}$ & 27.2 & $\mathrm{~b}$ & 26.8 \\
\hline & 10 & 29.4 & $34.6^{*}$ & ns & - & ns & 31.3 & ns & 31.0 \\
\hline & & $\begin{array}{l}0-30 \\
\mathrm{~cm}\end{array}$ & $\begin{array}{l}0-30 \\
\mathrm{~cm}\end{array}$ & $\begin{array}{l}0-30 \\
\mathrm{~cm}\end{array}$ & $\begin{array}{l}0-30 \\
\mathrm{~cm}\end{array}$ & $\begin{array}{l}0-30 \\
\mathrm{~cm}\end{array}$ & $\begin{array}{l}0-30 \\
\mathrm{~cm}\end{array}$ & $\begin{array}{l}0-30 \\
\mathrm{~cm}\end{array}$ & $\begin{array}{l}0-30 \\
\mathrm{~cm}\end{array}$ \\
\hline \multirow{6}{*}{$\begin{array}{l}\text { Sandy } \\
\text { soils }\end{array}$} & 1 & 30.1 & 29.8 & ns & 29.6 & ns & 27.4 & $\mathrm{~ns}$ & 27.6 \\
\hline & 2 & 21.4 & 22.5 & $\mathrm{a}$ & 20.7 & $\mathrm{a}$ & 20.3 & a & $15.9^{*}$ \\
\hline & 3 & 24.7 & 20.6 & ns & 20.4 & ns & $19.2^{*}$ & ns & $19.8^{*}$ \\
\hline & 4 & 26.4 & $17.2^{*}$ & $\mathrm{a}$ & - & & $16.4^{*}$ & $\mathrm{a}$ & $14.5^{*}$ \\
\hline & 5 & 26.8 & 24.0 & ns & 23.0 & ns & 23.9 & ns & 23.5 \\
\hline & 6 & 49.6 & $41.4^{*}$ & ns & $41.3^{*}$ & ns & $41.1^{*}$ & ns & $38.9^{*}$ \\
\hline \multirow{4}{*}{$\begin{array}{l}\text { Clayey } \\
\text { soils }\end{array}$} & 7 & 40.5 & 43.7 & ns & 43.1 & ns & 43.8 & ns & 43.5 \\
\hline & 8 & 70.5 & 77.4 & ns & - & & 76.1 & ns & 73.7 \\
\hline & 9 & 70.6 & 73.9 & $\mathrm{a}$ & 72.2 & $a b$ & 69.1 & $a b$ & 66.0 \\
\hline & 10 & 75.0 & 81.2 & ns & - & ns & 77.2 & $\mathrm{~ns}$ & 76.2 \\
\hline
\end{tabular}

Data represent the mean values for four replicates. "_" indicates that treatment was not evaluated. Means followed by the same letter within the line do not indicate significant difference by Tukey's test ( $<<0.05)$. Asterisk $(*)$ symbol indicates significant difference between the treatments of straw removal and baseline (before treatments setup) by Dunnett's test $(\mathrm{p}<0.05)$ for each soil depth.

\section{FIGURE CAPTIONS}

Fig.1 Geographic locations of the sites included in this study (Site 1=Itirapina/SP; Site 2=Quatá/SP; Site 3=Quatá/SP; Site 4=Quatá/SP; Site $5=$ Valparaíso/SP; Site 6=Quirinópolis/GO; Site 7=Capivari/SP; Site 8=Quirinópolis/GO; Site 9=Iracemápolis/SP; Site 10=Chapadão do Céu/GO). Sugarcane cultivation areas were processed according to the updated data from the Canasat's project (www.dsr.inpe.br/laf/canasat/)

Fig. 2 Annual SOC rates to a 30-cm depth in relation to the baseline (A) and NR treatment (B) in sandy and clayey soils. Asterisk $\left({ }^{*}\right)$ symbol indicates significant difference between the straw removal treatment 
and baseline (before treatments setup) by Dunnett test $(\mathrm{p}<0.05)$ for each soil depth. ([?]) symbol indicates significant difference between the straw removal treatment and NR treatment by Tukey test $(\mathrm{p}<0.05)$.

Fig. 3 Relationship between cumulative straw inputs and SOC stocks $(0-30 \mathrm{~cm}$ depth $)$ in the sandy and clayey soils. p [?] 0.05 indicates linear regression is significant; $\mathrm{ns}=$ not significant. (b) indicates $\mathrm{kg}$ of $\mathrm{C}$ in the soil per $\mathrm{Mg}$ of straw per hectare.

\section{Hosted file}

Graphical abstract.docx available at https://authorea.com/users/319223/articles/448973-doesstraw-retention-sustain-soil-carbon-stocks-in-brazilian-sugarcane-fields
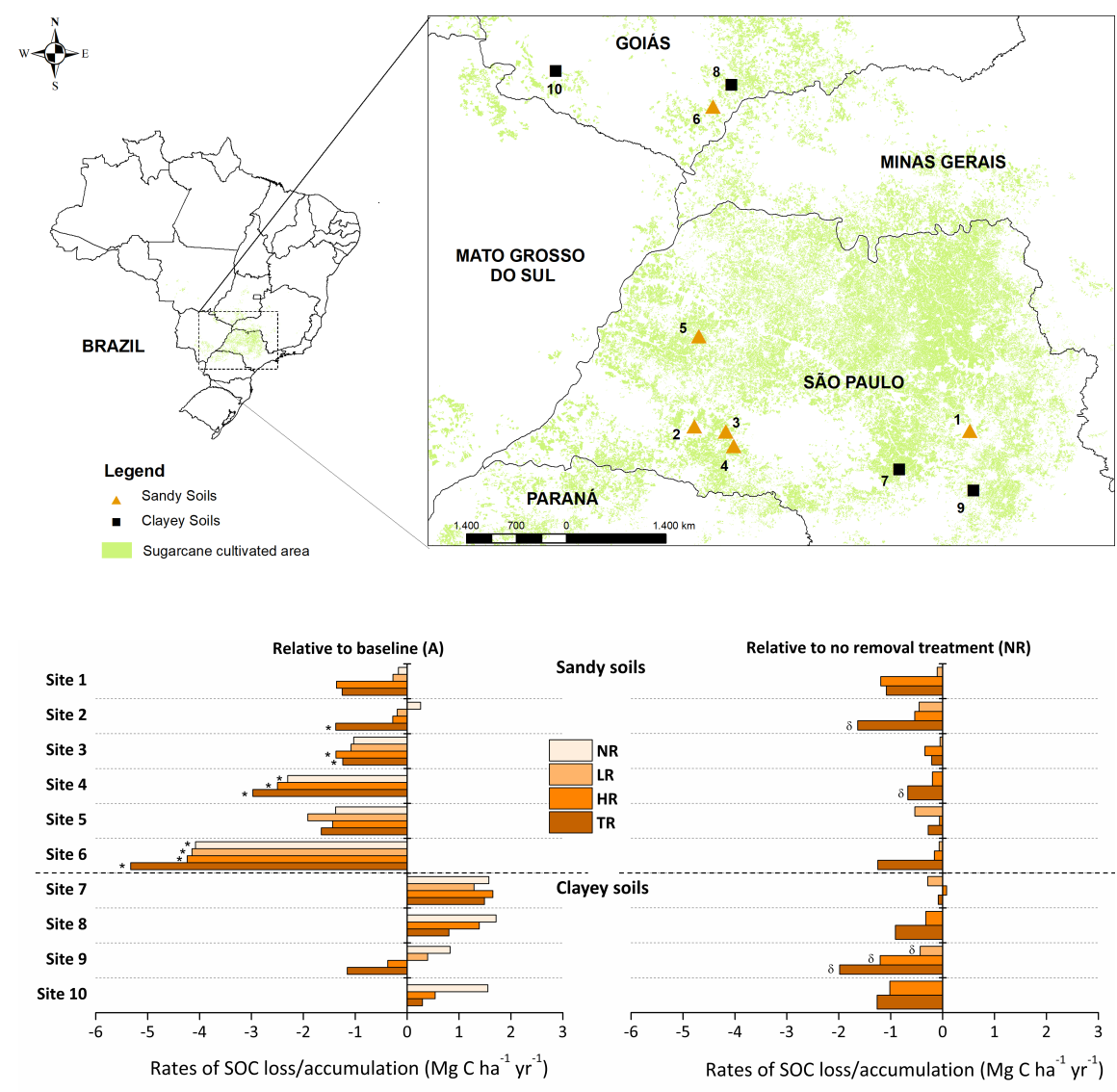


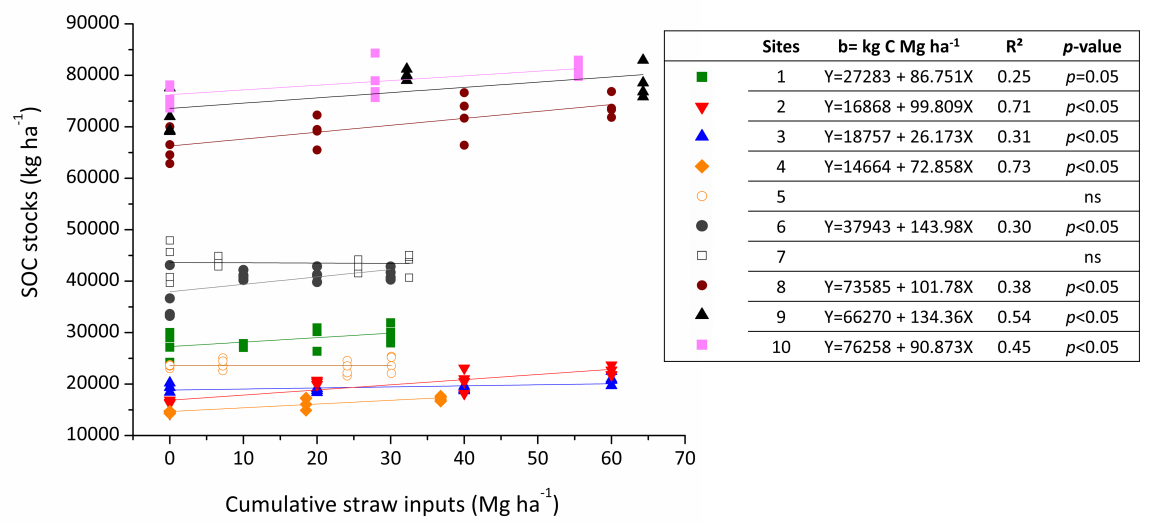

